\title{
Facile Preparation of Bioactive seco-Guaianolides and Guaianolides from Artemisia gorgonum and Evaluation of Their Phytotoxicity
}

\author{
Francisco A. Macías, ${ }^{* \dagger}$ Alejandro Santana, ${ }^{\dagger}$ Azusa Yamahata, $^{\dagger}$ Rosa M. Varela, ${ }^{\dagger}$ Frank R. Fronczek, ${ }^{\ddagger}$
} and José M. G. Molinillo ${ }^{\dagger}$

\author{
${ }^{\dagger}$ Allelopathy Group, Department of Organic Chemistry, School of Sciences, University of Cadiz, C/República Saharaui, s/n, \\ 11510-Puerto Real, Spain \\ ${ }^{\ddagger}$ Department of Chemistry, Louisiana State University, Baton Rouge, Louisiana 70803, United States
}

\section{Supporting Information}

ABSTRACT: Commercially available santonin was used to synthesize seven sesquiterpene lactones using a facile strategy that involved a high-yielding photochemical reaction. Three natural products from Artemisia gorgonum were synthesized in good yields, and in the case of two compounds, absolute configurations were determined from X-ray quality crystals. The structures previously reported for these compounds were revised. Sesquiterpene lactones were tested using the etiolated wheat coleoptile bioassay, and the most active compounds were assayed in standard target species. seco-Guaianolide (4) showed higher phytotoxic activities than the known herbicide

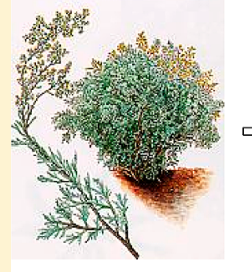

Artemisia gorgonum

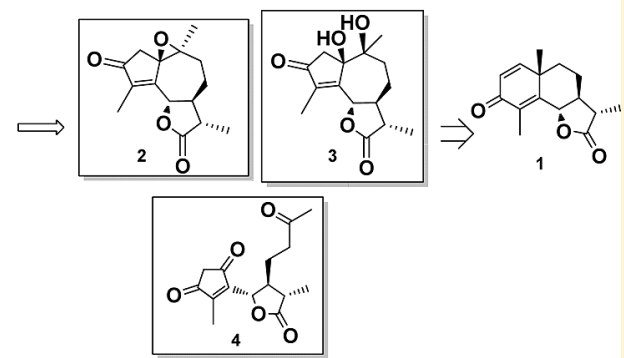

Logran. This high activity could be due to the presence of a cyclopentenedione ring. These results suggest that compound 4 should be involved in defense of A. gorgorum, displaying a wide range of activities that allow proposing them as new leads for development of a natural herbicide model with a seco-guaianolide skeleton.

$\mathrm{T}$ he intensive use of agrochemicals with identical modes of action has led to the development of more evolved biotypes with adaptations to the most common herbicides through several mechanisms, e.g., detoxification, changes in the active center, etc. ${ }^{1}$ In the case of weeds, resistance (cross and multiple) has been reported to almost all commercial herbicides, including glyphosate. ${ }^{2}$ The biotypes that have more than one mechanism of resistance to one or several different herbicides that act on a wide range of molecular targets are the most problematic weeds. This phenomenon is known as multiple resistance. ${ }^{3}$ The control of these biotypes is extremely difficult, as the number of possible alternative herbicides diminishes. New pesticides, including natural-based systems, are needed to combat this multiple resistance. ${ }^{4}$

Natural products provide a wider diversity of structures, stereostructures, skeletons, and functionalizations than synthetic compounds. ${ }^{5}$ Allelochemicals are natural herbicides that are synthesized by plants when in competition with other plants for soil and resources. ${ }^{6}$ These compounds exert their effect on numerous-as yet unknown-molecular targets. One obvious application of allelopathy is the use of allelopathic traits to develop methods for weed and pest control. Sesquiterpene lactones have been reported as allelopathic agents with high levels of bioactivity, and these compounds are particularly abundant in plants of the family Compositae. ${ }^{5,7}$ The sunflower is particularly noteworthy because of the economic importance of this crop and the abundance and variety of compounds of interest. ${ }^{8} \mathrm{~A}$ number of sesquiterpene lactones, such as the guaianolide dehydrozaluzanine $C,{ }^{9}$ have significant phytotoxic activity.

The endemic Cape Verdean Artemisia gorgonum is used in local folk medicine as a treatment for fever. Recently, sesquiterpene lactones 2,3 , and 4 have been isolated from this plant, and their good antimalarial activity has been demonstrated. ${ }^{10}$ Compound 3 was previously isolated from Artemisia adamsii, but the structure was initially proposed as 2. ${ }^{11}$ These compounds were all isolated in small amounts, and their synthesis is therefore required for further biological studies.

Herein we report the synthesis of these sesquiterpene lactones and an assessment of their phytotoxic activity and potential for production as new natural product-based herbicides. The key step in the proposed retrosynthetic reaction sequence (Scheme 1) is a high-yielding photochemical transformation of the readily available $\alpha$-santonin 1 . The structures of the natural products and their isomers $2,3,7$, and 8 have been revised. We also report the evaluation of the phytotoxic effects of these sesquiterpene lactones on several crops.

\section{RESULTS AND DISCUSSION}

Synthesis. Sesquiterpene lactones $\mathbf{2 - 8}$ were prepared by the reactions outlined in Scheme 2. The synthetic strategy

Received: September 18, 2012

Published: November 13, 2012 
Scheme 1. Retrosynthetic Analysis of the seco-Guaianolides and Guaianolides 2, 3, and 4

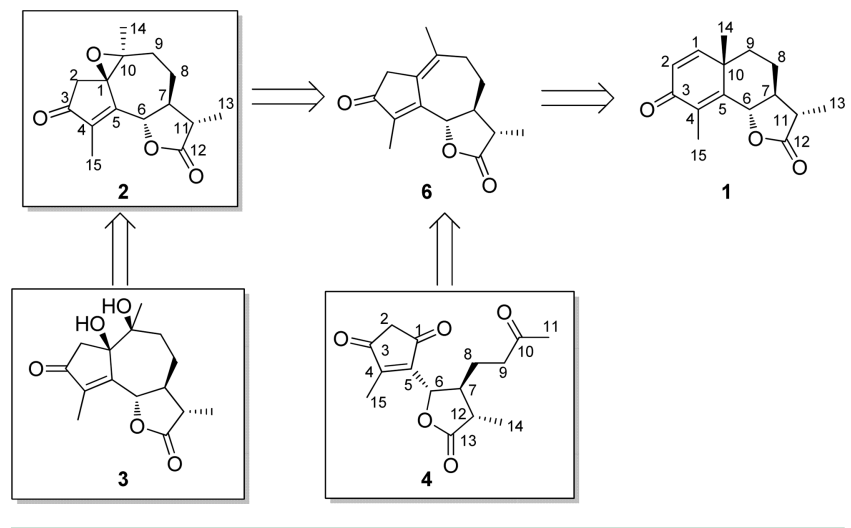

involves the transformation of $\alpha$-santonin, a commercial sesquiterpene lactone with the eudesmanolide structure, into the guaianolide isophotosantonin (5).

The reaction occurs through a photochemical process that has been known since $1957^{12}$ to provide an interesting source of functionalized guaianolide sesquiterpene lactones. The reaction was initially carried out in an acidic aqueous medium following the procedure recently published by Barbosa et al. to give the guaianolide isophotosantonin (5) in $32 \%$ yield. ${ }^{13}$ The photochemical reaction was optimized through an extensive study of the reaction conditions, and the yield was increased to $75 \%$. These results have no literature precedent. The main results are summarized in Table 1 . The yields were quantified by ${ }^{1} \mathrm{H}$ NMR spectroscopy on the crude reaction mixture with 1,3,5-trimethoxybenzene used as internal standard. This simple, rapid, and easy to implement approach was carried out according to the methodology developed by different groups. ${ }^{14}$

Photochemical reactions are renowned for the large amounts of byproducts that are often obtained, a characteristic that decreases the yields of target products. The use of filter solutions can improve results, and, for example, our group has
Table 1. Summary of the Optimization Study of the Photochemical Reaction to Obtain Isophotosantonin (5)

$\begin{array}{lrccccc}\text { no. } & \begin{array}{c}\text { time } \\ (\mathrm{h})\end{array} & \begin{array}{c}\text { acid/water } \\ \text { ratio } \\ (\mathrm{mL} / \mathrm{mL})\end{array} & \text { atmosphere } & \begin{array}{c}\text { filter } \\ \text { sol. }\end{array} & \begin{array}{c}\text { temperature } \\ \left({ }^{\circ} \mathrm{C}\right)\end{array} & \begin{array}{c}\text { yield } \\ (\%)\end{array} \\ 1 & 7 & 40 / 40 & \mathrm{Ar} & \mathrm{no} & \mathrm{rt} & 30 \\ 2 & 5 & 20 / 60 & \mathrm{Ar} & \text { no } & \mathrm{rt} & 17 \\ 3 & 5 & 10 / 50 & \mathrm{Ar} & \text { no } & \mathrm{rt} & 33 \\ 4 & 3 & 20 / 60 & \mathrm{Ar} & \text { no } & \text { reflux } & 0^{a} \\ 5 & 5 & 10 / 50 & \mathrm{Air} & \text { no } & \mathrm{rt} & 11 \\ 6 & 5 & 10 / 70 & \mathrm{Ar} & \text { yes } & \mathrm{rt} & 24 \\ 7 & 12 & 20 / 80 & \mathrm{Ar} & \text { yes } & 10 & 74 \\ 8 & 7 & 15 / 65 & \mathrm{Ar} & \text { Yes } & \sim 2 & 75 \\ 9 & 7 & 48 / 60 & & \text { no } & \text { reflux } & 17^{b} \\ 10 & 27 & 80 / 80 & \mathrm{~N}_{2} & \text { no } & \mathrm{rt} & 32^{c}\end{array}$

${ }^{a}$ Mainly isophotosantonic acid (9) was obtained. Isophotosantonin (5) was not observed. ${ }^{b}$ Conditions described by Barton. ${ }^{12}{ }^{c}$ Conditions described by Barbosa. ${ }^{23}$

reported the use of a solution of $\mathrm{Ni}$ (II) and $\mathrm{Co}$ (II) to restrict radiation below $3000 \AA \AA^{15}$ thus providing cleaner reactions without the formation of photoreduction products and with fewer byproducts. In this study cleaner reactions and better yields were obtained when the filter solution was used (entries $6-8)$. It is important to note that under these conditions only three products were observed: the starting material $\alpha$-santonin (1), isophotosantonic acid (9), and isophotosantonin (5). Lumisantonin (10) was not observed in any case.

Scheme 3. Structures of Isophotosantonic Acid (9) and Lumisantonin $(10)^{13}$

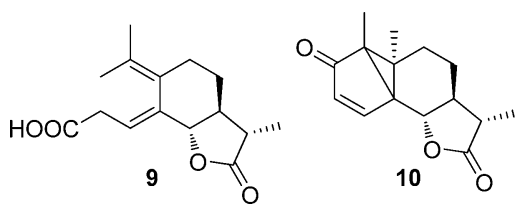

Scheme 2. Synthetic Route to seco-Guaianolides and Guaianolides 2, 3, and 4

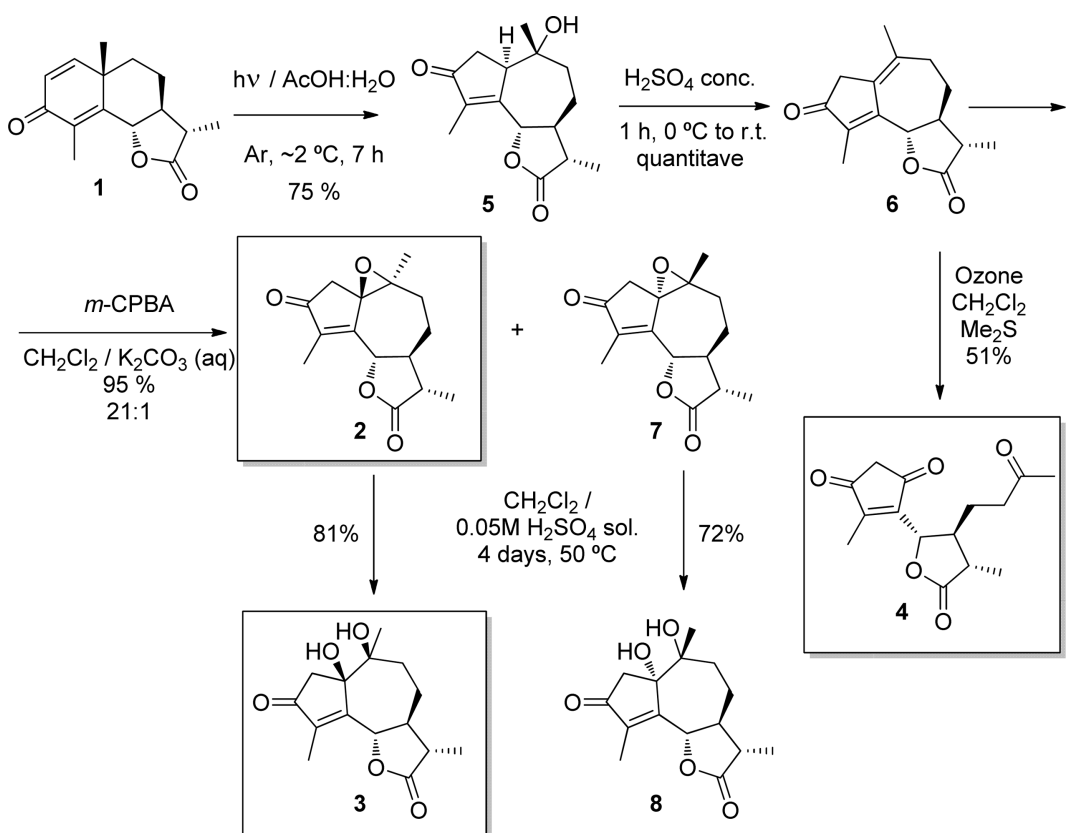


Reaction temperature was found to be an important parameter. Lower temperatures led to higher yields of isophotosantonin (5) (entries 7, 8), whereas high reaction temperatures generated only isophotosantonic acid (9) (entry 4). The reaction atmosphere also played a key role because the use of argon led to fewer byproducts and better yields (entries $3,5)$. Finally, the acid/water ratio has some influence on the results, with higher ratios giving the best yields.

The photochemical study revealed that isophotosantonin can be obtained in high yields by judicious choice of conditions and with significantly lower reaction times than previously reported (entry 8). An X-ray quality crystal of isophotosantonin (5) (as the monohydrate) was obtained for the first time (see Supporting Information, Figure S17). The configuration at C10 was confirmed to be $R$, with the $\mathrm{OH}$ group in an $\alpha$ orientation.

The diene 6 was obtained quantitatively by acid-mediated elimination of water from 5 . The procedure, adapted from Westwood et al., was previously used to eliminate an acetyl group at C-10 from the acetylated isophotosantonin. ${ }^{16,17}$ Products from the elimination at C-14 or C-9 were not observed.

Subsequent epoxidation of 6 by treatment with $m$-CPBA in a two-phase system $\left[\mathrm{CH}_{2} \mathrm{Cl}_{2} / \mathrm{KHCO}_{3}(\mathrm{aq})\right]$ led to a 21:1 mixture of natural compound 2 and the isomer 7 , with an overall yield of $95 \%$. Cleavage of the oxirane ring or rearrangements of acidsensitive species observed in other previously reported epoxidations were avoided by using this method. ${ }^{18}$ The spectroscopic data for compound $\mathbf{2}$ are identical to those described for the natural product isolated in $2008^{10}$ and prepared in 2009. ${ }^{16}$

Both previously described epoxides were reported with a different stereochemistry. This discrepancy was initially resolved by carrying out NMR NOESY studies on both isomers, with key correlations obtained for $\mathrm{H}-6 / \mathrm{H}-11 / \mathrm{H}-8 \beta$ and $\mathrm{H}_{3}-14 / \mathrm{H}-2 \alpha / \mathrm{H}-2 \beta / \mathrm{H}-9 \alpha / \mathrm{H}-9 \beta$ for the natural product and $\mathrm{H}-6 / \mathrm{H}-11 / \mathrm{H}-8 \beta$ and $\mathrm{H}_{3}-14 / \mathrm{H}-2 \alpha$ for the isomer of the natural product. The expected key correlation $\mathrm{H}-6 / \mathrm{H}-14$ was not observed, although this evidence is inconclusive. An X-ray quality crystal of the 1:5 EtOAc solvate of epoxide 2 was obtained by slow solvent evaporation (Figure 1). The $\beta$ -

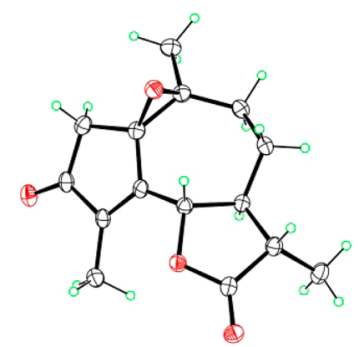

Figure 1. Crystal structure of compound 2 (ORTEP diagram).

orientation of the oxirane moiety in $\mathbf{2}$ was unequivocally established. The structure described ${ }^{10}$ for the natural compound should therefore be corrected as indicated. The ${ }^{1} \mathrm{H}$ NMR spectrum of compound 7 showed slight differences compared to compound 2. The spectroscopic data for both compounds are shown in Table 2. The most significant results are the chemical shifts for H-6 and H-7, which clearly indicate that 7 is the corresponding isomer of 2 , with the opposite configuration for the oxirane ring (i.e., the $\alpha$-orientation).
Table 2. ${ }^{1} \mathrm{H} \mathrm{NMR}^{a}$ and ${ }^{13} \mathrm{C} \mathrm{NMR}^{b}$ Spectroscopic Data (400 $\mathrm{MHz}, \mathrm{CDCl}_{3}$ ) for 1,10-Dioxa-isophotosantonin (2) and 1,10-Dioxa-isophotosantonin (7)

\begin{tabular}{|c|c|c|c|c|}
\hline \multirow[b]{2}{*}{ position } & \multicolumn{2}{|l|}{2} & \multicolumn{2}{|l|}{7} \\
\hline & $\delta_{\mathrm{H}}(\mathrm{ppm})(J$ in $\mathrm{Hz})$ & $\begin{array}{c}\delta_{\mathrm{C}} \\
(\mathrm{ppm})\end{array}$ & $\delta_{\mathrm{H}}(\mathrm{ppm})(J$ in $\mathrm{Hz})$ & 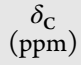 \\
\hline 1 & & 68.3 & & 68.6 \\
\hline $2 a$ & $2.72, \mathrm{~d}(18.8)$ & 40.8 & 2.67, d (19.2) & 39.3 \\
\hline $2 \mathrm{~b}$ & $2.57, \mathrm{~d}(18.8)$ & & 2.44, d (19.2) & \\
\hline 3 & & 203.1 & & 203.3 \\
\hline 4 & & 141.4 & & 146.1 \\
\hline 5 & & 159.1 & & 157.0 \\
\hline 6 & 4.82, dd $(10.4 ; 1.6)$ & 82.2 & 4.97, dd (11.0) & 77.5 \\
\hline 7 & $1.61, \mathrm{~m}$ & 50.2 & $2.86, \mathrm{~m}$ & 43.4 \\
\hline $8 \mathrm{a}$ & $1.84, \mathrm{~m}$ & 24.5 & $1.45, \mathrm{~m}$ & 23.6 \\
\hline $8 \mathrm{~b}$ & $1.59, \mathrm{~m}$ & & $1.45, \mathrm{~m}$ & \\
\hline $9 a$ & $2.36, \mathrm{dt}(4.4 ; 2.8)$ & 33.5 & $2.25, \mathrm{dt}(11.2 ; 4.0)$ & 28.8 \\
\hline $9 \mathrm{~b}$ & $2.01, \mathrm{dt}(4.9 ; 3.6)$ & & $2.06, \mathrm{dt}(11.2 ; 4.0)$ & \\
\hline 10 & & 66.0 & & 66.3 \\
\hline 11 & $2.30, \mathrm{dq}(14.0 ; 2.6)$ & 41.4 & $2.17, \mathrm{dq}(12.4 ; 2.3)$ & 42.5 \\
\hline 12 & & 177.3 & & 177.5 \\
\hline 13 & $1.26, \mathrm{~d}(7.2)$ & 12.9 & $1.22, \mathrm{~d}(7.2)$ & 12.8 \\
\hline 14 & $1.41, \mathrm{~s}$ & 25.7 & $1.41, \mathrm{~s}$ & 24.8 \\
\hline 15 & $2.00, \mathrm{~d}(2.0)$ & 9.3 & $2.01, \mathrm{~d}(1.6)$ & 10.0 \\
\hline
\end{tabular}

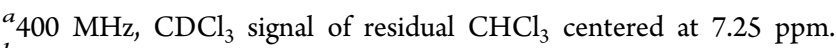
${ }^{b} 100 \mathrm{MHz}$, signals of $\mathrm{CDCl}_{3}$ centered at $77.0 \mathrm{ppm}$.

The epoxide cleavage reactions of 2 and 7 gave the unexpected syn-diols $\mathbf{3}$ and $\mathbf{8}$, respectively, in good yields of $81 \%$ and $72 \%$, respectively. Usually this reaction affords the trans-1,2-diols. ${ }^{10}$ The synthesis was carried out following a twophase acid hydrolysis with dilute $\mathrm{H}_{2} \mathrm{SO}_{4}$ and DCM. The spectroscopic data for the products are identical to those previously reported by the group of Bohlmann $(1985)^{11}$ and Ortet $(2008)^{10}$ for natural products whose structures were assigned as 7 and $\mathbf{1 1}$ (Scheme 4).

Scheme 4. Structures of Natural Products Proposed by Bohlmann and Ortet

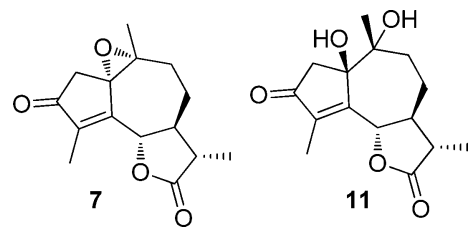

An X-ray quality crystal of syn-diol 3 was obtained under similar conditions to epoxide 2 (Figure 2), and the structure was corrected to 3 , a syn-diol with the hydroxy groups in a $\beta$ -

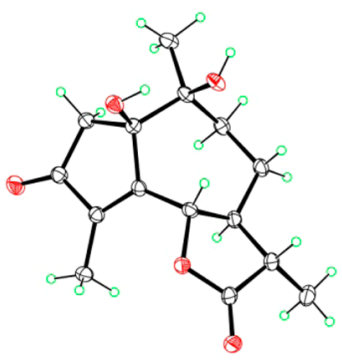

Figure 2. Crystal structure of compound 3 (ORTEP diagram). 
orientation. This finding suggests that the structure of the natural compound must also be revised. In 2009 Westwood and co-workers synthesized the syn-diols $\mathbf{3}$ and $\mathbf{8}$ using a different approach to obtain $87 \%$ yield of a $3: 1$ mixture described as inseparable diastereomers. Only the syn-diol 3 has been characterized with identical ${ }^{1} \mathrm{H}$ NMR and ${ }^{13} \mathrm{C}$ NMR spectra to those obtained in this work. The spectroscopic data for both syn-diols are shown in Table 3. The most significant differences

Table 3. ${ }^{1} \mathrm{H} \mathrm{NMR}^{a}$ and ${ }^{13} \mathrm{C} \mathrm{NMR}^{b}$ Spectroscopic Data (400 $\mathrm{MHz}, \mathrm{CDCl}_{3}$ ) for 1,10-Diol-isophotosantonin (3) and 1,10Diol-isophotosantonin (8)

\begin{tabular}{|c|c|c|c|c|}
\hline \multirow[b]{2}{*}{ position } & \multicolumn{2}{|l|}{3} & \multicolumn{2}{|l|}{8} \\
\hline & $\delta_{\mathrm{H}}(\mathrm{ppm})(J$ in $\mathrm{Hz})$ & $\begin{array}{c}\delta_{\mathrm{C}} \\
(\mathrm{ppm})\end{array}$ & $\delta_{\mathrm{H}}(\mathrm{ppm})(J$ in $\mathrm{Hz})$ & $\begin{array}{c}\delta_{\mathrm{C}} \\
(\mathrm{ppm})\end{array}$ \\
\hline 1 & & 80.4 & & 82.9 \\
\hline $2 \mathrm{a}$ & $2.52, \mathrm{~d}(18.0)$ & 46.6 & $2.89, \mathrm{~d}(12.0)$ & 48.4 \\
\hline $2 b$ & $2.43, \mathrm{~d}(18.4)$ & & $2.35, \mathrm{~d}(12.0)$ & \\
\hline 3 & & 205.4 & & 206.5 \\
\hline 4 & & 137.3 & & 141.3 \\
\hline 5 & & 165.2 & & 163.0 \\
\hline 6 & $5.25, \mathrm{dd},(10.4 ; 1.6)$ & 78.0 & 4.97, dd (11.0) & 82.4 \\
\hline 7 & $1.76, \mathrm{~m}$ & 52.6 & $2.66, \mathrm{~m}$ & 46.2 \\
\hline $8 a$ & $1.84, \mathrm{~m}$ & 23.2 & $1.66, \mathrm{~m}$ & 25.0 \\
\hline $8 b$ & $1.78, \mathrm{~m}$ & & $1.60, \mathrm{~m}$ & \\
\hline $9 \mathrm{a}$ & $2.10, \mathrm{dt},(4.4 ; 2.8)$ & 34.3 & $2.80, \mathrm{dt},(11.2 ; 4.0)$ & 37.3 \\
\hline $9 b$ & $1.46, \mathrm{dt}(4.9 ; 3.6)$ & & $2.33, \mathrm{dt}(11.2 ; 4.0)$ & \\
\hline 10 & & 74.0 & & 75.8 \\
\hline 11 & $2.37, \mathrm{dq}(14.0 ; 2.6)$ & 42.7 & $2.25, \mathrm{dq}(12.4 ; 2.3)$ & 41.6 \\
\hline 12 & & 177.8 & & 178.3 \\
\hline 13 & $1.22, \mathrm{~d}(7.2)$ & 12.8 & $1.23, \mathrm{~d}(7.2)$ & 12.3 \\
\hline 14 & $1.24, \mathrm{~s}$ & 26.2 & $1.40, \mathrm{~s}$ & 29.0 \\
\hline 15 & $1.80, \mathrm{~s}$ & 8.4 & $1.86, \mathrm{~s}$ & 9.6 \\
\hline
\end{tabular}

${ }^{a} 400 \mathrm{MHz}, \mathrm{CDCl}_{3}$ signal of residual $\mathrm{CHCl}_{3}$ centered at $7.25 \mathrm{ppm}$. ${ }^{b} 100 \mathrm{MHz}$, signals of $\mathrm{CDCl}_{3}$ centered at $77.0 \mathrm{ppm}$.

are the chemical shifts of the signals for H-6, H-7, H-9a, and H$9 \mathrm{~b}$. These results indicate that $\mathbf{8}$ is the corresponding isomer of 3 , with the opposite orientation for the hydroxy groups (i.e., $\alpha$ orientation). This is the first time that 3 and 8 have been prepared, isolated, and unequivocally characterized separately.

The next challenge was to synthesize natural product 4 . Diene 6 was converted into seco-guaianolide (4) in good yield by oxidation with ozone in a cold solution using dry DCM and $\mathrm{Me}_{2} \mathrm{~S}$. The ${ }^{1} \mathrm{H}$ and ${ }^{13} \mathrm{C}$ NMR spectra of the product are identical to those reported for the natural product. ${ }^{10}$

In summary, the natural products 2,3 , and 4 were obtained in 3 or 4 steps with overall yields of $68 \%, 55 \%$, and $38 \%$, respectively.

Bioactivity. The natural products were tested for growth of Plasmodium falciparum, and they displayed weak activity. The cytotoxic activity was subsequently evaluated on the growth of the VERO cell line, and the compounds showed weak activity in all cases. (Complete bioassay data are provided in the Supporting Information, Tables S1 and S2.) Following our procedure for the preselection of compounds to be tested for phytotoxicity, we initially assessed the sesquiterpene lactones 1-8 using the etiolated coleoptile bioassay carried out with the following concentrations: $1 \mathrm{mM}, 500 \mu \mathrm{M}, 100 \mu \mathrm{M}, 50 \mu \mathrm{M}, 10$ $\mu \mathrm{M}$. Bioassay data are shown in Figure 3, where negative values signify inhibition, positive values denote activation, and zero represents the control. All compounds, with the exception of

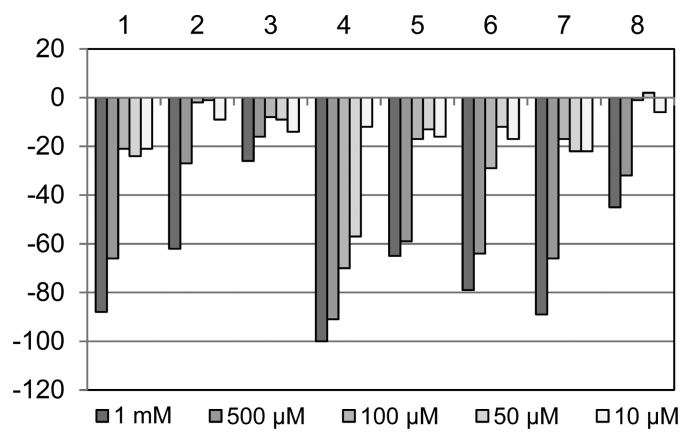

Figure 3. Etiolated coleoptile bioassay.

diols 3 and 8, displayed high levels of phytotoxic activity [1, $-88 \% 1 \mathrm{mM},-66 \% 500 \mu \mathrm{M} ; 2,-62 \% 1 \mathrm{mM} ; 5,-65 \% 1 \mathrm{mM}$, $-59 \% 500 \mu \mathrm{M} ; 6,-79 \% 1 \mathrm{mM},-64 \% 500 \mu \mathrm{M} ; 7,-89 \% 1$ $\mathrm{mM},-66 \% 500 \mu \mathrm{M}]$. In particular, seco-guaianolide (4) gave a remarkable activity even when tested at the lowest concentration $[50 \mu \mathrm{M}]$, and this is clearly the most active compound in the series $[4,-100 \% 1 \mathrm{mM},-91 \% 500 \mu \mathrm{M},-70 \% 100 \mu \mathrm{M}$, $-57 \% 50 \mu \mathrm{M}]$.

All the sesquiterpene lactones except diols 3 and 8 were evaluated in the phytotoxicity bioassay using the standard target species Lepidium sativum (cress), Allium cepa (onion), Lactuca sativa (lettuce), and Lycopersicum esculentum (tomato) and the commercial herbicide Logran as internal standard. ${ }^{19}$ The concentrations tested in the phytotoxicity assay were identical to those in the previous bioassay. Once again, seco-guaianolide (4) gave the highest phytotoxic activity [L. sativum (root, $-85 \% 1 \mathrm{mM},-82 \% 500 \mu \mathrm{M}$; shoot, $-71 \% 1 \mathrm{mM},-58 \% 500$ $\mu \mathrm{M}$ ), A. сера (root, $-84 \% 1 \mathrm{mM},-80 \% 500 \mu \mathrm{M},-74 \% 100$ $\mu \mathrm{M}$; shoot, $-86 \% 1 \mathrm{mM},-82 \% 500 \mu \mathrm{M}$ ), L. sativa (root, $-91 \% 1 \mathrm{mM},-88 \% 500 \mu \mathrm{M},-66 \% \mu \mathrm{M}$; shoot, $-77 \% 1 \mathrm{mM}$, $-45 \% 500 \mu \mathrm{M}$ ), and L. esculentum (germination, $-89 \% 1 \mathrm{mM}$, $-70 \% 500 \mu \mathrm{M}$; root, $-90 \% 1 \mathrm{mM},-87 \% 500 \mu \mathrm{M}$; shoot, $-78 \% 1 \mathrm{mM},-73 \% 500 \mu \mathrm{M})]$. The results for compound 4 and for Logran, for each plant seed in germination and root and shoot lengths, are shown in Figures 4-7. In general, 4 showed

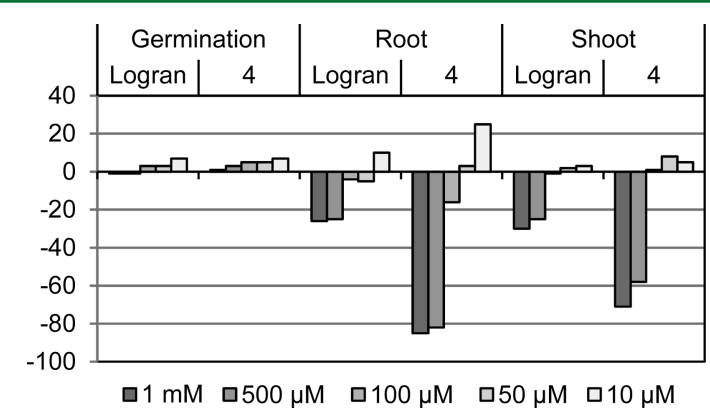

Figure 4. Cress bioassay compared to Logran.

inhibition levels higher than or similar to Logran, particularly at higher concentrations $[1 \mathrm{mM}$ and $500 \mu \mathrm{M}]$. This activity is more significant on cress and onion, where the activity is greater than that shown by the commercial herbicide.

The natural product seco-guaianolide (4) has a cyclopentenedione ring, which is uncommon in natural products. Such compounds are rare, but they have shown significant biological activities. One such example is spiromamakone A, which was isolated from the extract of a cultured nonsporulating fungal endophyte derived from the New Zealand 


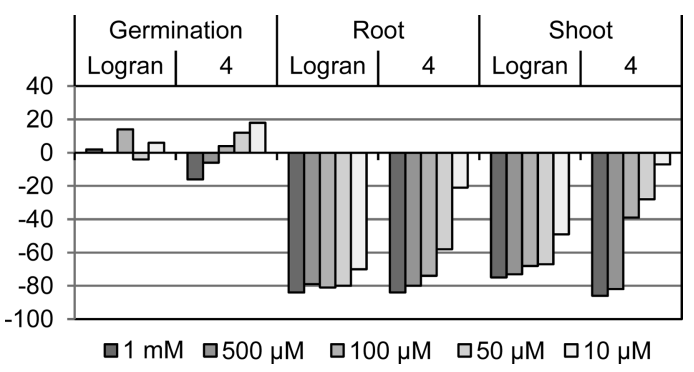

Figure 5. Onion bioassay compared to Logran.

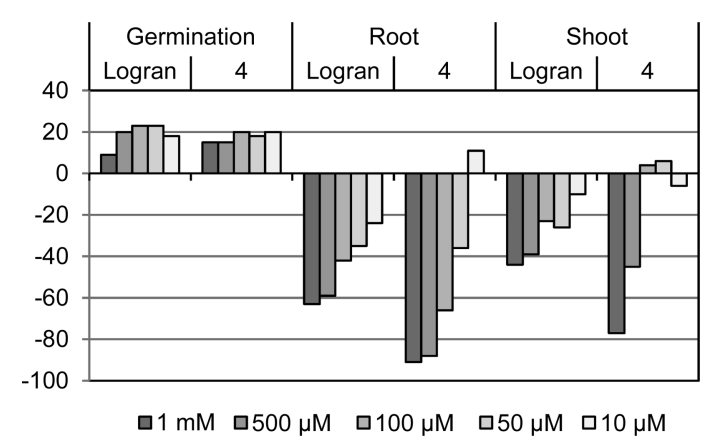

Figure 6. Lettuce bioassay compared to Logran.

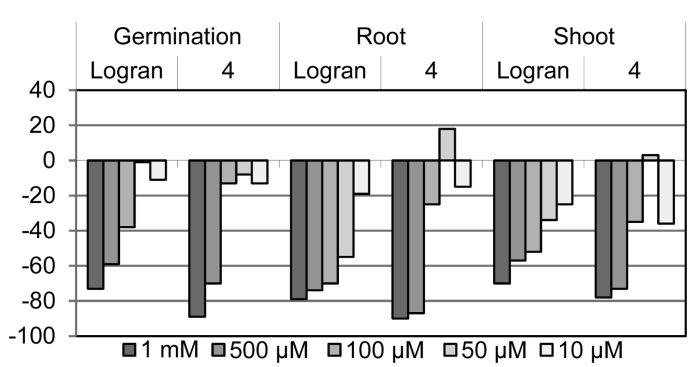

Figure 7. Tomato bioassay compared to Logran.

native tree Knightia excelsa (rewarewa). This represents a new structural entity and is a potent cytotoxic and antimicrobial agent. ${ }^{20}$ Another example is found in the chemical constituents of the endophytic fungus Preussia sp., which led to the isolation of new spirobisnaphthalene analogues such as spiropreussione A. This compound showed cytotoxicity toward A2780 and BEL-7404 cells with $\mathrm{IC}_{50}$ values of 2.4 and $3.0 \mu \mathrm{M}$, respectively. $^{21}$

\section{CONCLUSIONS}

The synthesis of natural products 2,3 , and $\mathbf{4}$ was achieved in good overall yields, and the structures of guaianolides 2 and 3 were established by X-ray crystallography, with the structures previously reported by Bohlmann and Ortet revised. All compounds showed good phytotoxic activity, especially the seco-guaianolide (4), which showed remarkable activity that was higher than the internal standard Logran. This interesting activity could be related to the presence of a cyclopentenedione ring in the structure of the natural product. We will continue to elucidate the structural requirements for activity in these compounds based on intensive structure-activity studies.

\section{EXPERIMENTAL SECTION}

General Experimental Procedures. All melting points are uncorrected, and optical rotations were measured using a PerkinElmer polarimeter (model 241) set on the sodium D line. Infrared spectra were recorded on a Perkin-Elmer FT-IR Spectrum 1000 Mattson 5020 system. HR-MS results were determined using VG 1250 or VG Autospect instruments at $70 \mathrm{eV} .{ }^{1} \mathrm{H}$ NMR, ${ }^{1} \mathrm{H}-{ }^{1} \mathrm{H}$ gCOSY, ${ }^{1} \mathrm{H}-{ }^{13} \mathrm{C}$ gHSQC, and ${ }^{1} \mathrm{H}-{ }^{13} \mathrm{C}$ gHMBC NMR spectra were obtained at 399.954 and $100.565 \mathrm{MHz}$ for ${ }^{13} \mathrm{C}$ NMR on a Varian INOVA-400 spectrometer using $\mathrm{CDCl}_{3}$ as solvent. Chemical shifts are given in parts per million with respect to residual ${ }^{1} \mathrm{H}$ signals of $\mathrm{CDCl}_{3}\left(\delta_{\mathrm{H}}\right.$ $7.25)$ and ${ }^{13} \mathrm{C}$ signals of $\mathrm{CDCl}_{3}\left(\delta_{\mathrm{C}} 77.00\right)$. Column chromatography was performed on silica gel (35-75 mesh), and TLC analysis was carried out using aluminum precoated silica gel plates. Synthetic products were purified by preparative HPLC using a Lichrosorb silica 60 semipreparative column (Lichrospher $\mathrm{SiO}_{2}$, Merck, 7 and $10 \mu \mathrm{m}$, $150 \times 10 \mathrm{~nm})$ and analytical columns Lichrosorb silica 60 (LiChrospher $\mathrm{SiO}_{2}$, Merck, 7 and $10 \mu \mathrm{m}, 250 \times 10 \mathrm{~mm}$ ) and Phenomex Luna [Phenomex Luna Silica (2), $10 \mu \mathrm{m}, 100 \mathrm{~A}$ ] in conjunction with a Hitachi Lachrom D-7000 PLC system with a Hitachi L-7490 RI detector and Hitachi L-7420 UV detector. All solvents were spectroscopy grade or were distilled from glass prior to use. $\alpha$-Santonin was obtained from Sigma-Aldrich.

General Photochemical Reactions: NMR Yield Calculation Procedure. Photochemical reaction crude mixtures were analyzed by ${ }^{1} \mathrm{H}$ NMR spectroscopy using the internal standard 1,3,5-trimethoxybenzene to calculate the molecular weight of a given compound by eq 1 , where the subscript $(\mathrm{u})$ means unknown in reference to the different products present in the crude mixture and the subscript (i) means internal standard. The $(m)$ represents the moles, $(P)$ the number of protons per molecule, and $(A)$ the area of the peaks or cluster of peaks. The basis for the quantitative use of ${ }^{1} \mathrm{H}$ NMR is derived from the direct proportional relationship between the area of the proton resonance signal and the number of protons in the observed resonance. This relationship has been proposed as a method for the determination of the molecular weight of unknown compounds by different groups. ${ }^{14}$ Additionally the molecular weight permits the calculation of yield, which is compared with the yield obtained by traditional purification of products.

$$
m_{\mathrm{u}}=\frac{A_{\mathrm{u}} P_{\mathrm{i}} m_{\mathrm{i}}}{A_{\mathrm{i}} P_{\mathrm{u}}}
$$

General X-ray Experimental Data. Crystal structures of $\mathbf{5}$ monohydrate, 2.1/5 EtOAc, and 3 were determined using data collected with $\mathrm{Cu} \mathrm{K} \alpha$ radiation $(\lambda=1.54178 \AA)$ at low temperature on a Bruker Kappa Apex-II diffractometer. Absolute configurations of all structures were determined by refinement of the Flack parameter. ${ }^{22}$

Crystal data for 5 monohydrate: $\mathrm{C}_{15} \mathrm{H}_{20} \mathrm{O}_{4} \cdot \mathrm{H}_{2} \mathrm{O}, M_{\mathrm{r}}=282.33$, orthorhombic space group $P 22_{1} 2_{1} 2_{1}, a=7.6345(10) \AA, b=13.862(2)$ $\AA, c=13.927(2) \AA, V=1473.9(4) \AA^{3}, Z=4, \rho_{\text {calcd }}=1.272 \mathrm{~g} \mathrm{~cm}^{-3}, \mu=$ $0.78 \mathrm{~mm}^{-1}, T=90 \mathrm{~K}, 9639$ data collected with $\theta<68.7^{\circ}, R=0.025$ ( $I$ $>2 \sigma(I)), R_{\mathrm{w}}=0.066$ (all data) for 2624 unique data and 194 refined parameters, Flack $x=0.01$ (13) for 1076 Friedel pairs, CCDC 884581. Crystal data for 2.EtOAc solvate: $\mathrm{C}_{15} \mathrm{H}_{18} \mathrm{O}_{4} \cdot 1 / 5 \mathrm{C}_{4} \mathrm{H}_{8} \mathrm{O}_{2}, M_{\mathrm{r}}=279.91$, orthorhombic space group $P 22_{1} 2_{1} 2_{1}, a=7.3918$ (2) $\AA, b=29.7040$ (10) $\AA, c=32.1937(10) \AA, V=7068.6(4) \AA^{3}, Z=20, \rho_{\text {calcd }}=1.315 \mathrm{~g} \mathrm{~cm}^{-3}$, $\mu=0.78 \mathrm{~mm}^{-1}, T=90 \mathrm{~K}, 57945$ data collected with $\theta<68.4^{\circ}, R=$ $0.029(I>2 \sigma(I)), R_{\mathrm{w}}=0.077$ (all data) for 12751 unique data and 929 refined parameters, Flack $x=0.00(7)$ for 5549 Friedel pairs, CCDC 884582. Crystal data for 3: $\mathrm{C}_{15} \mathrm{H}_{20} \mathrm{O}_{5}, M_{\mathrm{r}}=280.31$, orthorhombic space group $P 2_{1} 2_{1} 2_{1}, a=9.0581(4) \AA, b=9.5429(4) \AA, c=$ $15.5537(7) \AA, V=1344.47(10) \AA^{3}, Z_{\mathrm{e}}=4, \rho_{\text {calcd }}=1.385 \mathrm{~g} \mathrm{~cm}^{-3}, \mu=$ $0.86 \mathrm{~mm}^{-1}, T=90 \mathrm{~K}, 12926$ data collected with $\theta<69.5^{\circ}, R=0.027$ $(I>2 \sigma(I)), R_{\mathrm{w}}=0.072$ (all data) for 2467 unique data and 191 refined parameters, Flack $x=0.10(14)$ for 1024 Friedel pairs, CCDC 884583. Supplementary data in CIF format can be obtained free of charge from The Cambridge Crystallographic Data Centre via www.ccdc.cam.ac. uk/data_request/cif.

General Methodology. Isophotosantonin (5). Based on a modification of the method described by Barbosa and co-workers ${ }^{23}$ and Barton and co-workers, ${ }^{12} \alpha$-santonin $(100 \mathrm{mg}, 0.41 \mathrm{mmol})$ was dissolved in $\mathrm{HOAc}(15 \mathrm{~mL})$ and $\mathrm{H}_{2} \mathrm{O}(65 \mathrm{~mL})$ and stirred in a modified Hanovia reactor cooled with ice-water with a $\mathrm{Ni}(\mathrm{II})$ and 
$\mathrm{Co}$ (II) aqueous solution as a filter (the filter solution contained $46 \mathrm{~g}$ of $\mathrm{NiSO}_{4} \cdot 6 \mathrm{H}_{2} \mathrm{O}$ and $14 \mathrm{~g}$ of $\mathrm{CoSO}_{4} \cdot 7 \mathrm{H}_{2} \mathrm{O}$ per $100 \mathrm{~mL}$ of water). The reaction mixture was degassed by a flow of $\mathrm{Ar}$ for $5 \mathrm{~min}$ and was then irradiated with a $125 \mathrm{~W}$ mercury lamp at $0{ }^{\circ} \mathrm{C}$ for $7 \mathrm{~h}$. The mixture was concentrated under reduced pressure after addition of cyclohexane. The product was purified by column chromatography (EtOAc/nhexane $=70: 30)$. Isophotosantonin (5) was obtained as a white solid (81 mg, $75 \%$ yield): $\mathrm{mp} 145-146{ }^{\circ} \mathrm{C}$; $[\alpha]^{20}{ }_{\mathrm{D}}+105.0\left(c 1.12, \mathrm{CH}_{3} \mathrm{Cl}\right)$; IR (thin film) $\nu_{\max } 3466,2973,2932,2878,1775,1701,1641,1456$, 1340, 1312, 1232, 1177, 1154, 1134, 1099, 991,752 cm ${ }^{-1}$; ${ }^{1} \mathrm{H}$ NMR data are identical to those reported by Barbosa et al. ${ }^{13} \mathrm{X}$-ray quality crystals of pure isophotosantonin (5) were obtained by slow evaporation of an EtOAc solution (data submitted to CCDC (CCDC 884581)).

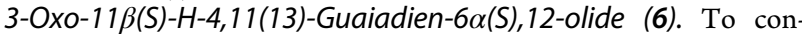
centrated $\mathrm{H}_{2} \mathrm{SO}_{4}(10 \mathrm{~mL})$ at $0{ }^{\circ} \mathrm{C}$ was added isophotosantonin (5) $(200 \mathrm{mg}, 0.75 \mathrm{mmol})$ portionwise over $10 \mathrm{~min}$, and the mixture was stirred for a further $10 \mathrm{~min}$. The ice bath was removed, and the mixture was allowed to warm to room temperature and stirred for 50 $\min$. The resulting brown solution was poured into ice-water and was allowed to warm to room temperature before extracting with DCM (3 $\times 60 \mathrm{~mL}$ ). The combined organic layers were washed with $5 \% \mathrm{NaOH}$ solution $(20 \mathrm{~mL})$ and $\mathrm{H}_{2} \mathrm{O}$ and brine $(20 \mathrm{~mL})$ and dried over anhydrous $\mathrm{Na}_{2} \mathrm{SO}_{4}$. The solvent was removed under reduced pressure to give the diene $6(185 \mathrm{mg}, 0.75 \mathrm{mmol})$ as a white solid in quantitative yield: $\mathrm{mp} 87-90^{\circ} \mathrm{C} ;{ }^{1} \mathrm{H}$ NMR data are identical to those reported by Westwood et al. ${ }^{16}$

$1 \beta(R), 10 \beta(S)$-Epoxy-3-oxo-11 $\beta(S) H-4,11(13)$-guaien-6 $\alpha(S), 12$ -

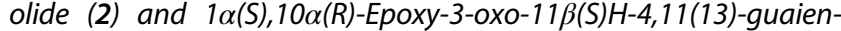
$\sigma \alpha(S), 12$-olide (7). To a solution of diene $6(200 \mathrm{mg}, 0.81 \mathrm{mmol})$ in DCM $(14 \mathrm{~mL})$ was added m-CPBA $(280 \mathrm{mg}, 1.62 \mathrm{mmol})$ and saturated aqueous $\mathrm{KHCO}_{3}(14 \mathrm{~mL})$. The mixture was stirred for $3 \mathrm{~h}$ at room temperature. The reaction was quenched with $\mathrm{NaOH}(5 \mathrm{~mL}, 0.5$ M). DCM was added, the layers were separated, and the aqueous phase was extracted with DCM. The combined organic layers were washed with brine, dried $\left(\mathrm{MgSO}_{4}\right)$, and concentrated, and the residue was purified by HPLC (EtOAc $/ n$-hexane $=55: 45$, flow $12 \mathrm{~mL} / \mathrm{min}$ ) to give two fractions. The major fraction was the naturally occurring epoxide 2, and the other contained the isomer 7. Natural epoxide 2 was obtained as a white solid (193 mg, yield 91\%). The fraction corresponding to its isomer was purified by HPLC using an analytical column $($ EtOAc $/ n$-hexane $=55: 45$, flow $3 \mathrm{~mL} / \mathrm{min})$. The isomer and the natural compound were separated in a 21:1 ratio of 2:7 with an overall yield $95 \%$. The spectroscopic data for the two compounds are shown in Table 2. Epoxide 2: $\mathrm{mp} 125-127{ }^{\circ} \mathrm{C}$ (reported: mp 134$\left.136{ }^{\circ} \mathrm{C}^{16}\right)$; $[\alpha]^{20}{ }_{\mathrm{D}}-59.0\left(\mathrm{c} 1, \mathrm{CH}_{3} \mathrm{Cl}\right)$; IR (thin film) $\nu_{\max } 3499,2971$, 2930, 2878, 1786, 1714, 1644, 1413,1379, 1313, 1297, 1232, 1167, $1079,1042,1011,957,804,752,633,603 \mathrm{~cm}^{-1}$; X-ray quality crystals of 2 were obtained by slow evaporation of an EtOAc solution of pure epoxide, and the structure of the natural compound was confirmed (data submitted to CCDC (CCDC 884582)).

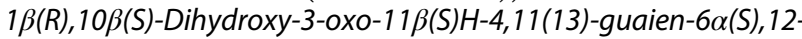
olide (3) and $1 \alpha(S), 10 \alpha(R)$-Dihydroxy-3-oxo-11 $1(S) H-4,11(13)$ guaien- $6 \alpha(S), 12$-olide (8). To a solution of epoxide 2 or 7 (100 $\mathrm{mg}, 0.38 \mathrm{mmol})$ in DCM $(20 \mathrm{~mL})$ was added a solution of $\mathrm{H}_{2} \mathrm{SO}_{4}(20$ $\mathrm{mL}, 0.05 \mathrm{M})$. The mixture was heated under reflux and stirred for $4 \mathrm{~d}$ at $50{ }^{\circ} \mathrm{C}$. The reaction was quenched with saturated aqueous $\mathrm{K}_{2} \mathrm{CO}_{3}$ $(\sim \mathrm{pH} 9) . \mathrm{H}_{2} \mathrm{O}(20 \mathrm{~mL})$ and $\mathrm{DCM}(20 \mathrm{~mL})$ were added. The product was extracted with DCM $(4 \times 20 \mathrm{~mL})$, and the combined organic layers were washed with brine. Compound 3 was obtained in $81 \%$ yield $(87 \mathrm{mg})$, and compound 8 in $72 \%$ yield $(72 \mathrm{mg})$. The spectroscopic data for both compounds are shown in Table 3. Product 3: $\mathrm{mp} 125-127^{\circ} \mathrm{C}$; $[\alpha]^{20}{ }_{\mathrm{D}}-82.1\left(\mathrm{c} 1, \mathrm{CH}_{3} \mathrm{Cl}\right)$; IR (thin film) $\nu_{\max }$ $3448,2974,2934,2876,1777,1710,1654,1457,1379,1300,1237$, $1167,1141,1086,1060,1026,999,879,754 \mathrm{~cm}^{-1}$; X-ray quality crystals of 3 were obtained by slow evaporation of an EtOAc solution of pure epoxide, and the structure of the natural compound was confirmed (data submitted to CCDC (CCDC 884583)). Diol 8: $[\alpha]^{20}{ }_{\mathrm{D}}+71.8\left(c 0.05, \mathrm{CH}_{3} \mathrm{Cl}\right)$; IR (thin film) $\nu_{\max } 3442,2926,1762$,
$1700,1458,1376,1316,1261,1235,1175,1014,986,919,801,733$ $\mathrm{cm}^{-1}$.

4-Methyl-5-[(2S,3S, 4S)-4-methyl-5-oxo-3-(3-oxobutyl)tetrahydrofuran-2-yl]-cyclopent-4-ene-1,3-dione (4). Ozone was introduced to a solution of diene $6(100 \mathrm{mg}, 0.41 \mathrm{mmol})$ in dry DCM $(30 \mathrm{~mL})$ at $-75{ }^{\circ} \mathrm{C}$, and the mixture was stirred until the solution became blue, at which point the addition of ozone was stopped. $\mathrm{Me}_{2} \mathrm{~S}$ was carefully added $(2 \mathrm{~mL})$ dropwise. The reaction mixture was stirred for $2 \mathrm{~d}$, and the solvent was washed with saturated aqueous $\mathrm{NaCl}$. The dried compounds were separated by $\mathrm{CC}$ using silica gel (EtOAc $/ n$-hexane $=40: 60,50: 50)$. seco-Guaianolide (4) was obtained as a white solid in $51 \%$ yield $(53 \mathrm{mg}): \mathrm{mp} 125-127^{\circ} \mathrm{C}$; $[\alpha]_{D}^{20}-82.1\left(c 1, \mathrm{CH}_{3} \mathrm{Cl}\right)$; IR (thin film) $\nu_{\max } 3448,2974,2934,2876$, $1777,1710,1654,1457,1379,1300,1237,1167,1141,1086,1060$, $1026,999,879,754 \mathrm{~cm}^{-1} ;{ }^{1} \mathrm{H}$ and ${ }^{13} \mathrm{C}$ NMR data are identical to those reported by Ortet et al. ${ }^{10}$

Coleoptiles Bioassay. Wheat seeds (Triticum aestivum L. cv. Duro) were sown in $15 \mathrm{~cm}$ Petri dishes moistened with $10 \mathrm{~mL}$ of distilled $\mathrm{H}_{2} \mathrm{O}$ and were grown in the dark at $22 \pm 1{ }^{\circ} \mathrm{C}$ for 3 days. The roots and caryopses were removed from the shoots. Roots were placed in a Van der Wijt guillotine, and the apical $2 \mathrm{~mm}$ were cut off and discarded. The next $4 \mathrm{~mm}$ portion of each coleoptile was cut and used for the bioassay. All manipulations were performed under a green safelight. Fractions and extracts were predissolved in DMSO, and this led to the final bioassay concentration with a maximum of $0.1 \%$ DMSO, with dilution using phosphate-citrate buffer $(2 \mathrm{~mL})$ containing $2 \%$ sucrose at $\mathrm{pH}$ 5.6. Parallel controls were performed with the same DMSO concentration.

\section{ASSOCIATED CONTENT}

\section{S Supporting Information}

NMR spectra of sesquiterpene lactones $\mathbf{2 - 8}$, crystal structures of 2,3 , and 5 , and additional bioassay data are available free of charge via the Internet at http://pubs.acs.org.

\section{AUTHOR INFORMATION}

\section{Corresponding Author}

*Tel: +34.956012770. Fax: +34.956 016288. E-mail: famacias@ uca.es.

\section{Notes}

The authors declare no competing financial interest.

\section{ACKNOWLEDGMENTS}

This research was supported by the Ministerio de Ciencia y Tecnología, Spain (MCYT; Project No. AGL2008-04716/ AGR), and Consejería de Innovación, Ciencia e Industria (P07FQM-03031).

\section{DEDICATION}

In memory of Horace G. Cutler.

\section{REFERENCES}

(1) (a) Gressel, J. Molecular Biology of Weed Control; Taylor \& Francis: London, 2002; p 504. (b) Powles, S. B.; Shaner, D. L. Herbicide Resistance and World Grains; CRC Press: Boca Raton, FL, 2001; p 308. (c) Prado, R. D.; Jorrin, J.; García-Torres, L. Weed and Crop Resistance to Herbicides; Kluwer Academic: Dordrecht, 1997; p 340.

(2) (a) Powles, S. B.; Lorraine-Colwill, D. F.; Dellow, J. J.; Preston, C. Weed Sci. 1998, 46, 604-607. (b) Shaner, D. L.; Lindenmeyer, R. B.; Ostlie, M. H. Pest Manage. Sci. 2012, 68, 3-9.

(3) Heap, I. M. Pestic. Sci. 1997, 51, 235-243.

(4) Dayan, F. E.; Cantrell, C. L.; Duke, S. O. Bioorg. Med. Chem. 2009, 17, 4022-4034.

(5) Henkel, T.; Brunne, R. M.; Müller, H.; Reichel, F. Angew. Chem., Int. Ed. 1999, 38, 643-647. 
(6) Macías, F. A.; Molinillo, J. M. G.; Varela, R. M.; Galindo, J. C. G. Pest Manage. Sci. 2007, 63, 327-348.

(7) Macías, F. A.; Fernández, A.; Varela, R. M.; Molinillo, J. M. G.; Torres, A.; Alves, P. L. C. A. J. Nat. Prod. 2006, 69, 795-800.

(8) (a) Macías, F. A.; Molinillo, J. M. G.; Galindo, J. C. G.; Varela, R. M.; Torres, A.; Simonet, A. M. Allelopathic Studies in Cultivar Species. 13. Terpenoids with Potential Use as Natural Herbicide Templates. Section Title: Agrochemical Bioregulators; 1999; pp 15-31.

(b) Macías, F. A.; Oliva, R. M.; Varela, R. M.; Torres, A.; Molinillo, J. M. G. Phytochemistry 1999, 52, 613-621. (c) Macías, F. A.; Torres, A.; Molinillo, J. M. G.; Varela, R. M.; Castellano, D. Phytochemistry 1996, 43, 1205-1215. (d) Macías, F. A.; Varela, R. M.; Torres, A.; Molinillo, J. M. G. Phytochemistry 1993, 34, 669-674.

(9) Macias, F. A.; Galindo, J. C. G.; Molinillo, J. M. G.; Castellano, D. Phytochemistry 2000, 54, 165-171.

(10) Ortet, R.; Prado, S.; Mouray, E.; Thomas, O. P. Phytochemistry 2008, 69, 2961-2965.

(11) Bohlmann, F.; Hartono, L.; Jakupovik, J.; Huneck, S. Phytochemistry 1985, 24, 1003-1007.

(12) Barton, D. H. R.; De Mayo, P.; Shafiq, M. J. Chem. Soc. 1957, 929-935.

(13) Alvarenga, E. S.; Barbosa, L. C. A.; Saliba, W. A.; Arantes, F. F. P.; Demuner, A. J.; Silva, A. Quim. Nova 2009, 32, 401-406.

(14) (a) Rundlöf, T.; Mathiasson, M.; Bekiroglu, S.; Hakkarainen, B.; Bowden, T.; Arvidsson, T. J. Pharm. Biomed. Anal. 2010, 52, 645-651. (b) Pauli, G. F.; Jaki, B. U.; Lankin, D. C. J. Nat. Prod. 2005, 68, 133149.

(15) Macías, F. A.; Molinillo, J. M. G.; Massanet, G. M.; RodríguezLuis, F. Tetrahedron 1992, 48, 3345-3352.

(16) Makiyi, E. F.; Frade, R. F. M.; Lebl, T.; Jaffray, E. G.; Cobb, S. E.; Harvey, A. L.; Slawin, A. M. Z.; Hay, R. T.; Westwood, N. J. Eur. J. Org. Chem. 2009, 5711-5715.

(17) Chowdhury, P. K.; Sharma, R. P.; Thyagarajan, G.; Herz, W.; Govindan, S. V. J. Org. Chem. 1980, 45, 4993-4997.

(18) Macías, F. A.; Chinchilla, D.; Molinillo, J. M. G.; Marin, D.; Varela, R. M.; Torres, A. Tetrahedron 2003, 59, 1679-1683.

(19) Macías, F. A.; Castellano, D.; Molinillo, J. M. G. J. Agric. Food. Chem. 2000, 48, 2512-2521.

(20) Van der Sar, S. A.; Blunt, J. W.; Munro, M. H. G. Org. Lett. 2006, 8, 2059-2061.

(21) Chen, X.; Shi, Q.; Lin, G.; Guo, S.; Yang, J. J. Nat. Prod. 2009, $72,1712-1715$.

(22) Flack, H. D. Acta Crystallogr. 1983, A39, 876-881.

(23) Arantes, F. F.; Barbosa, L. C.; Alvarenga, E. S.; Demuner, A. J.; Bezerra, D. P.; Ferreira, J. R.; Costa-Lotufo, L. V.; Pessoa, C.; Moraes, M. O. Eur. J. Org. Chem. 2009, 44, 3739-3745. 